\title{
What factors affect the pelagic cladocerans of the meso-eutrophic Azibo Reservoir?
}

\author{
A.M. Geraldes ${ }^{1}$, M.J. Boavida ${ }^{2}$ \\ ${ }^{1}$ CIMO, Escola Superior Agraria de Bragança, Campus de Santa Apolonia, 5301-885 Bragança, Portugal. E-mail: geraldes@ipb.pt \\ ${ }^{2}$ Centro de Biologia Ambiental, Departamento de Biologia Animal, Faculdade de Ciências da Universidade de Lisboa, Campo Grande C8 1749- \\ 016 Lisboa, Portugal. E-mail: mjboavida @ fc.ul.pt
}

\begin{abstract}
The assemblage patterns of pelagic Cladocera species were investigated in a meso-eutrophic reservoir from January 2000 to December 2002. Trends of environmental factors (water temperature, conductivity, $\mathrm{pH}$, and nutrient concentrations), as well as of biotic factors (availability of potentially edible phytoplankton and densities of herbivorous and carnivorous copepods) were assessed. Zooplankton community was dominated by Cladocera and Copepoda. Assemblage patterns for Cladocera were identified by performing a cluster analysis on abundance data of the dominant species: Daphnia longispina, Ceriodaphnia pulchella, Bosmina longirostris and Diaphanosoma brachyurum. In winter and spring, Daphnia was dominant. In early summer and end of autumn, Ceriodaphnia and Daphnia coexisted. During summer, Ceriodaphnia was dominant and coexisted with Diaphanosoma. Bosmina was present in low densities during the whole study period. Cladoceran populations exhibited non-synchronous peaks of abundance, evidencing different ecological optima. Temperature seemed to be the main structuring factor of this assemblage. The way biotic interactions influenced pelagic cladoceran assemblage in this reservoir was not clear and needs further research.
\end{abstract}

Keywords: Zooplankton, Cladocera, Copepoda, environmental factors, phytoplankton availability.

\section{Introduction}

Zooplankton composition, abundance and dynamics are structured by both environmental factors and biotic interactions (Wetzel 2001). The understanding of the way those structural forces interact constitutes an important source of information to implement correct management practices, in order to maintain water quality of reservoirs in a perspective of multiple-use approach. Cladocerans are important components of lakes and reservoirs, because of their significant role in the functioning of those ecosystems. As grazers, they may influence phytoplankton dynamics and consequently the relationships between chlorophyll and nutrients (Lampert \& Sommer 1997, Tessier et al. 2001). Cladocerans also regulate bacterioplankton and protozoan populations as well as detritus availability, because under certain conditions they feed on those items (Schneider-Olt \& Adrian 2001). Consequently, they will interfere on the epilimnetic cycle of organic matter by reducing seston concentrations, thus modifying particle sedimentation rates (Bossard \& Uehlinger
1993, Sommer et al. 2003). On the other hand, cladocerans are important in food web linkage. They can be an important food source for carnivorous copepods (Kerfoot 1978), for aquatic insect larvae such as those of Chaoboridae (Schum \& Maly 2000), and for 0+ fish and adult planktivorous fish (Siegfried \& Kopache 1984, Beklioglu \& Moss 1996).

This study focuses on the pelagic cladoceran assemblage patterns in Azibo Reservoir, an impoundment built in the Portuguese part of River Douro catchment. The main goals of the study were: (1) to characterise cladoceran assemblage patterns; (2) to assess the influence of environmental factors upon this assemblage; (3) to determine the availability of the potentially edible phytoplankton; (4) to determine the densities of the copepods Copidodiaptomus numidicus Gurney (a potential competitor) and Acanthocyclops robustus Sars (a potential predator); (5) to attempt to qualitatively evaluate the potential impact of fish predation on the cladoceran assemblage. 


\section{Study area}

Azibo Reservoir is located in the Portuguese part of River Douro catchment. The area of the reservoir is 410 ha and its total capacity is $54470 \times 10^{3} \mathrm{~m}^{3}$. Maximum depth is about $30 \mathrm{~m}$, mean depth is $13.2 \mathrm{~m}$ and water retention time is approximately 2.22 years. This reservoir was filled for the first time in 1982 and it is used mainly for recreation. Minor uses are water supply and irrigation. As water use is not very intense, annual water level fluctuations are of small magnitude, ranging between 1.5 and $2 \mathrm{~m}$. This fact allows for the existence of large beds of emergent macrophytes in part of the shallow littoral area of this reservoir (Fig. 1). The direct influence of human activities on the impoundment is greatest during summer, when the reservoir and surroundings are used for recreation such as fishing, swimming, camping and boating. Farming and grazing (mainly sheep) are activities found all over the year in the surroundings. In this area, annual precipitation varies between 800 and $1000 \mathrm{~mm}$ and mean annual air temperature ranges between $12.5^{\circ} \mathrm{C}$ and $14^{\circ} \mathrm{C}$. During the period of study thermal stratification occur-

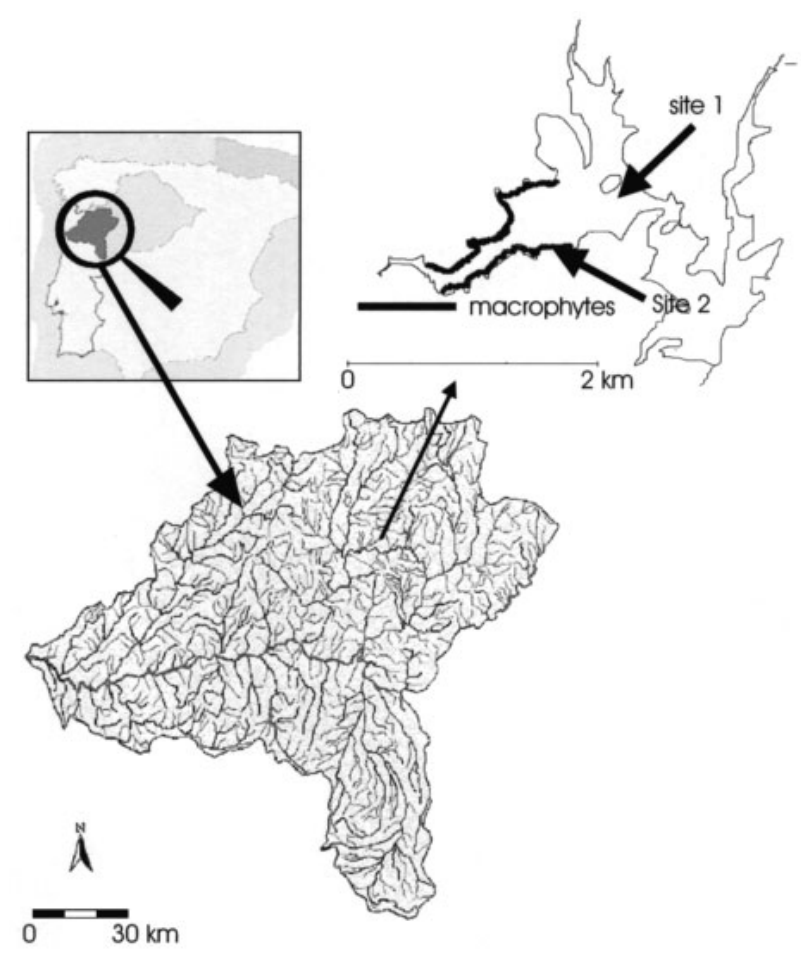

Fig. 1. Location of Azibo Reservoir with indication of sampling station. red from June to October and the reservoir was classified as meso-eutrophic. Further information concerning this reservoir can be found in Geraldes \& Boavida (2003).

\section{Materials and methods}

Samples were collected monthly in winter and biweekly in summer, from January 2000 to December 2002 at one single sampling station, located at the deepest area of the reservoir (site 1). Zooplankton samples were obtained on each sampling date by taking two vertical hauls using a Wisconsin type net of $64 \mu \mathrm{m}$ mesh size. Animals were anaesthetised with carbonated water and preserved in sugar-saturated formaldehyde ( $4 \% \mathrm{v} / \mathrm{v}$ final concentration). Depending on density, zooplankton were counted in 5, 10, $20 \mathrm{ml}$ subsamples or in total sample. Animals were always identified to species level, according to Scourfield \& Harding (1966), Margaritora (1983) and Dussart (1969); for phytoplankton analysis integrated water samples were collected from the euphotic zone. Samples were fixed «in situ» in Lugol's solution. Phytoplankton were counted according to Utermöhl (1958), using an inverted microscope at 200X/400X magnification. Algae were identified to genus, according to Bourrelly (1966, 1968, 1970). Fish assemblage characterisation was based on local angler information.

Water samples for soluble reactive phosphorus (SRP) and total phosphorus (TP) determinations were obtained from the upper $30-40 \mathrm{~cm}$ stratum, from the middle water column ( 7 to $10 \mathrm{~m}$ ) and from the bottom into acid rinsed bottles, and were transported to the laboratory in a cold container. SRP concentrations were estimated by the method of Murphy \& Riley (1962) and TP was assessed after acid hydrolysis with persulfate for $60 \mathrm{~min}$ under high temperature and pressure (APHA 1989). Chlorophyll $a$ (CHL $a$ ) was obtained from 500 to $1000 \mathrm{ml}$ of integrated water sample filtered through a Whatman GF/A filter no more than $2 \mathrm{~h}$ after collection. Concentrations were determined spectrophotometrically after overnight extraction in $90 \%$ acetone. Environmental variables such as water temperature, dissolved oxygen, conductivity, $\mathrm{pH}$, as well as nitrate $\left(\mathrm{N}-\mathrm{NO}_{3}\right)$, ammonium ion $\left(\mathrm{N}-\mathrm{NH}_{4}\right)$ and ammonia gas $\left(\mathrm{N}-\mathrm{NH}_{3}\right)$ were measured in situ at $1 \mathrm{~m}$ intervals with a 6820 YSI Multiparameter Water Quality Monitor. Water transparency was measured with a $20 \mathrm{~cm}$ diameter black and white Secchi disk.

The general procedure recommended by Green \& Vascotto (1978) was used to characterise cladoceran assemblage patterns. Cluster analysis (UPGMA meth- 
od, Pearson distance measure) allowed identification of cladoceran patterns. This analysis was performed on $\log (\mathrm{x}+1)$ transformed abundance data of the dominant cladoceran species. Subsequently, a Kruskal-Wallis test was carried out for each environmental factor, for phytoplankton and for copepod densities. In this way it was found whether the obtained clusters varied significantly from each other in what concerned mean value of each environmental factor and each alga and copepod mean densities. All statistical analyses were performed using SYSTAT 8.0 (SPSS, 1998)

\section{Results}

\section{Zooplankton community and characterisation of cladoceran assemblage}

Cladoceran species in Azibo were: Daphnia longispina Müller, Ceriodaphnia pulchella Sars, Bosmina longirostris Müller, Diaphanosoma brachyurum Liéven, Alona costata Sars, Alona rectangula Sars, Alona quadrangularis Müller, Chydorus sphaericus Müller and Daphnia pulex de Geer. However, Alona spp., Chydorus sphaericus and Daphnia pulex were only found in less than $5 \%$ of total samples in very low densities and consequently they were considered as occasional and were not taken into account in the statistical analyses. Although not the main focus of investigation, Rotifera and Copepoda were recorded because these organisms are important components of the zooplankton and because of their trophic interactions with cladocerans. Rotifera were dominated by Polyarthra spp., Asplanchna priodonta Gosse, Keratella cochlearis Gosse, and Conochilus spp.. Two species of Copepoda were found; the calanoid Copidodiaptomus numidicus and the cyclopoid Acanthocyclops robustus, the former dominating over the latter. Since Rotifera was not a very representative taxon in this reservoir (Fig. 2) only interactions between Cladocera and Copepoda were focused. Daphnia densities ranged bet-

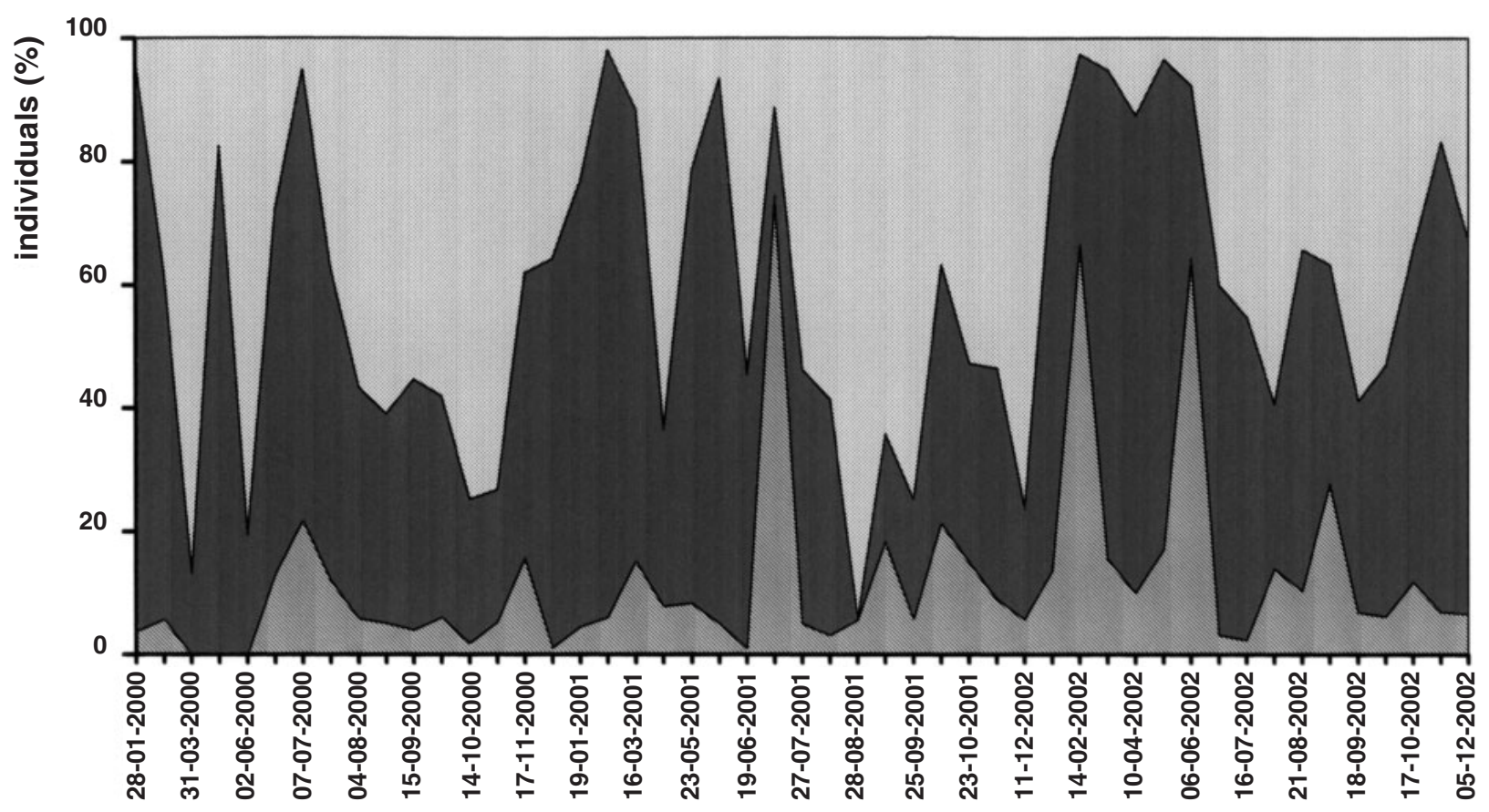

Rotifera $\square$ Copepoda $\square$ Cladocera

Fig. 2. Relative abundance (\%) of Rotifera, Copepoda and Cladocera in Azibo Reservoir. 
ween 27 and 8021 ind. $/ \mathrm{m}^{3}$ in 2000 , between 0 and 9549 ind.$/ \mathrm{m}^{3}$ in 2001 and between 0 and 1560 ind. $/ \mathrm{m}^{3}$ in 2002. Ceriodaphnia varied between 0 and 24,605
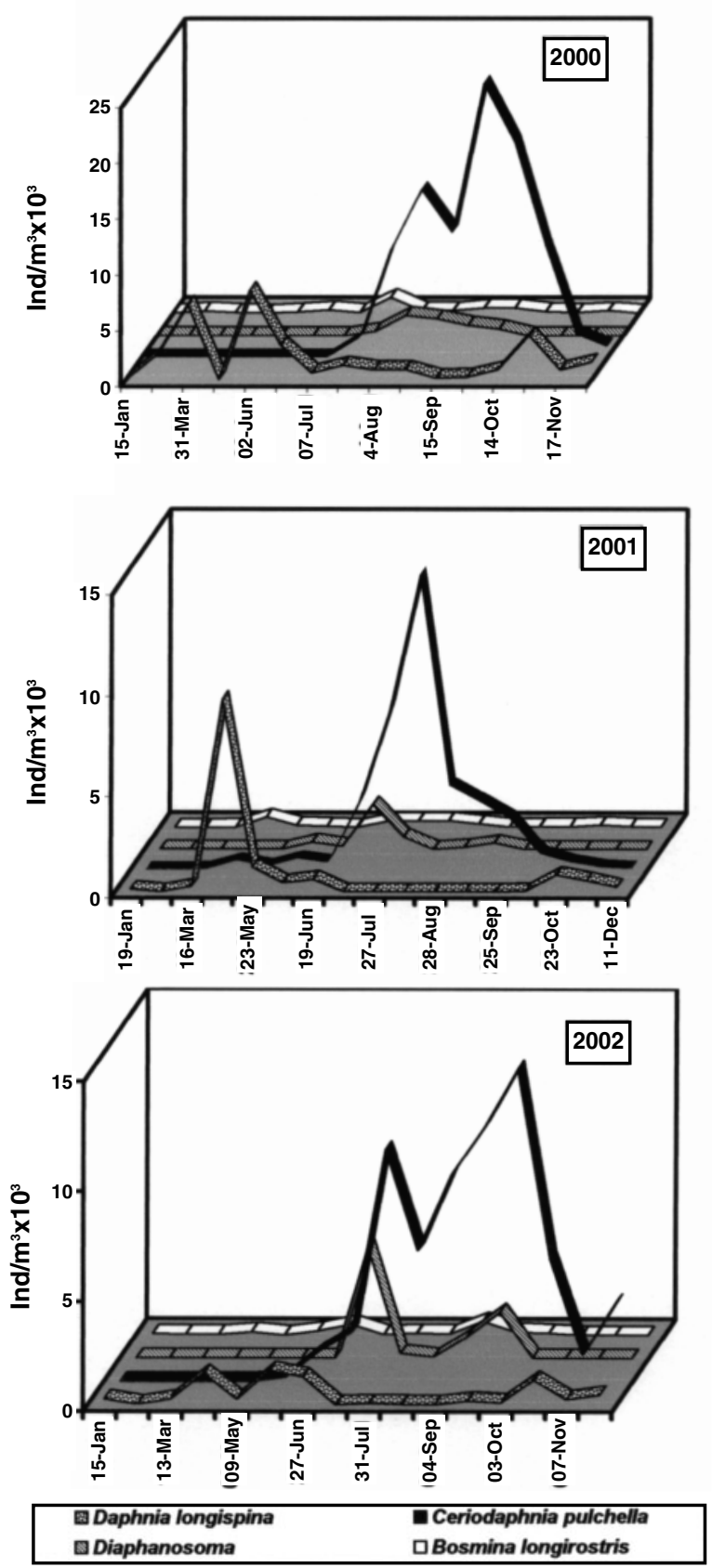

Fig. 3. Seasonal and inter-annual variation of cladoceran densities in Azibo Reservoir. ind. $/ \mathrm{m}^{3}$ in 2000 , between 8 and 14,610 ind. $/ \mathrm{m}^{3}$ in 2001 and between 0 and $14,197 \mathrm{ind} . / \mathrm{m}^{3}$ in 2002. Bosmina ranged from 0 to 1401 ind.$/ \mathrm{m}^{3}$ in 2000 , from 3 to 509 ind. $/ \mathrm{m}^{3}$ in 2001 and from 0 to 637 ind. $/ \mathrm{m}^{3}$ in 2002 . Even at times in low densities, this cladoceran was almost always present in samples. Diaphanosoma was present only in summer months and during this season its density varied between 419 and 1783 ind. $/ \mathrm{m}^{3}$ in 2000, between 96 and 2196 ind.$/ \mathrm{m}^{3}$ in 2001 and bet-

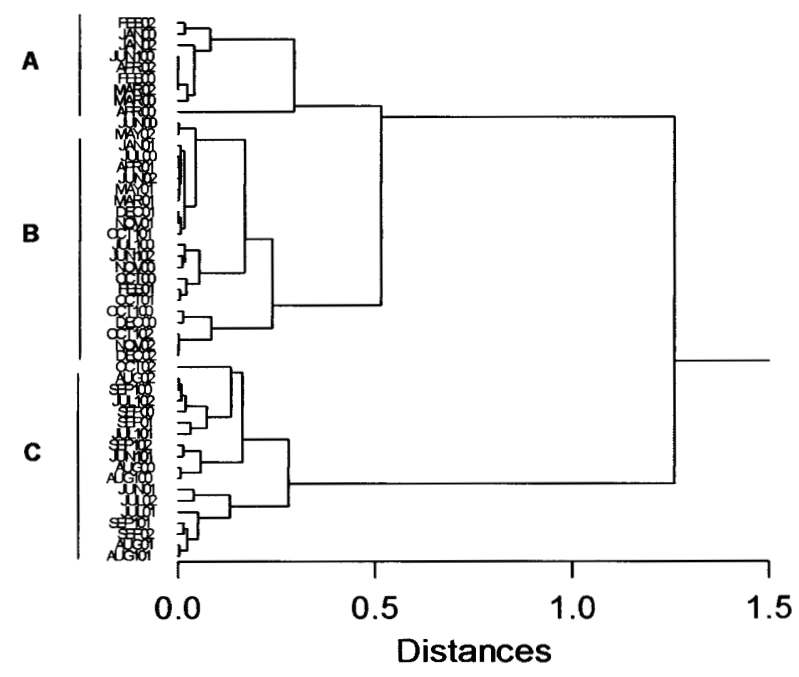

Fig. 4. Dendrogram depicting the three clusters resulting from multivariate analysis based on cladoceran densities.

ween 64 and 5061 ind. $/ \mathrm{m}^{3}$ in 2002 (Fig. 3). Considering Daphnia, Ceriodaphnia, Bosmina and Diaphanosoma densities, three clusters were obtained (Fig. 4): (A) Dapnhia was dominant and coexisted with Bosmina (samples obtained from January to June 2000 and from January to April 2002); (B) Daphnia, Ceriodaphnia and Bosmina coexisted (samples obtained in $2 \mathrm{Ju}-$ ne 2000, July 2000, from October 2000 to May 2001, from October 2001 to December 2001, from May to June 2002 and from 17 October to December 2002); (C) Ceriodaphnia was dominant and coexisted with Bosmina and Diaphanosoma. Dapnhia was not detected or was present at very low densities (samples obtained from August to September 2000, from June to September 2001 and from July to 3 October 2002). 


\begin{tabular}{|c|c|c|c|c|c|}
\hline \multirow[t]{2}{*}{ Variables } & \multicolumn{3}{|c|}{ Clusters } & \multirow[b]{2}{*}{$\chi^{2}$} & \multirow[b]{2}{*}{ P-Value } \\
\hline & $\mathbf{A}$ & B & C & & \\
\hline Precipitation (mm) & 61.2 & 33.3 & 132.5 & 11.18 & 0.002 \\
\hline $\begin{array}{l}\text { Water transparency }(\mathrm{m}) \\
\text { Water temperature }\left({ }^{\circ} \mathrm{C}\right)\end{array}$ & 3.8 & 5.1 & 3.7 & 8.73 & 0.015 \\
\hline Surface & 10.5 & 21.8 & 15.0 & 24.95 & 0.001 \\
\hline Middle water column & 11.9 & 19.5 & 14.0 & 19.68 & 0.002 \\
\hline Bottom & 9.6 & 10.9 & 10.4 & 5.16 & 0.069 \\
\hline \multicolumn{6}{|l|}{ Dissolved oxygen $\left(\mathrm{mg} \mathrm{l}^{-1}\right)$} \\
\hline Surface & 9.2 & 8.7 & 8.7 & 1.22 & 0.441 \\
\hline Middle water column & 9.1 & 7.9 & 8.7 & 6.00 & 0.070 \\
\hline Bottom & 8.2 & 1.2 & 5.1 & 21.97 & 0.001 \\
\hline \multicolumn{6}{|l|}{ Conductivity $\left(\mu \mathrm{S} \mathrm{cm}^{-1}\right)$} \\
\hline Surface & 55 & 69 & 59 & 14.86 & 0.001 \\
\hline Middle water column & 56 & 65 & 57 & 8.32 & 0.030 \\
\hline Bottom & 55 & 60 & 56 & 2.68 & 0.500 \\
\hline \multicolumn{6}{|l|}{ pH } \\
\hline Surface & $6.9-7.4$ & $7.0-8.5$ & $5.4-8.1$ & 7.43 & 0.020 \\
\hline Middle water column & $6.9-8.2$ & $6.6-8.4$ & $6.6-8.5$ & 5.21 & 0.060 \\
\hline Bottom & $6.7-7.7$ & $6.2-7.6$ & $5.2-8.0$ & 1.25 & 0.553 \\
\hline \multicolumn{6}{|l|}{$\mathrm{N}-\mathrm{NO}_{3}\left(\mathrm{mg} \mathrm{l}^{-1}\right)$} \\
\hline Surface & 2.2 & 3.5 & 6.8 & 5.34 & 0.069 \\
\hline Middle water column & 1.4 & 2.6 & 7.2 & 8.00 & 0.024 \\
\hline Bottom & 1.1 & 1.3 & 6.3 & 11.47 & 0.004 \\
\hline \multicolumn{6}{|l|}{$\mathrm{N}-\mathrm{NH}_{4}\left(\mathrm{mg} \mathrm{I}^{-1}\right)$} \\
\hline Surface & 0.1 & 0.6 & 0.5 & 1.08 & 0.584 \\
\hline Middle water column & 0.1 & 0.9 & 0.6 & 2.66 & 0.335 \\
\hline Bottom & 0.1 & 1.7 & 0.9 & 1.57 & 0.555 \\
\hline \multicolumn{6}{|l|}{$\mathbf{T P}\left(\mu \mathrm{g} \mathrm{I}^{-1}\right)$} \\
\hline Surface & 49.4 & 69.9 & 61.6 & 10.73 & 0.005 \\
\hline Middle water column & 67.2 & 80.8 & 65.4 & 7.74 & 0.024 \\
\hline Bottom & 55.9 & 119.0 & 75.7 & 23.15 & 0.001 \\
\hline \multicolumn{6}{|l|}{$\operatorname{SRP}\left(\mu \mathrm{g} \mathrm{I}^{-1}\right)$} \\
\hline Surface & 5.5 & 5.9 & 6.3 & 0.20 & 0.906 \\
\hline Middle water column & 5.7 & 10.8 & 6.3 & 9.31 & 0.010 \\
\hline Bottom & 5.4 & 15.7 & 10.0 & 10.09 & 0.003 \\
\hline
\end{tabular}




\section{Influence of environmental, abiotic factors upon cladocerans}

Variables such as precipitation, water transparency, water temperature, conductivity, $\mathrm{pH}, \mathrm{TP}$ and $\mathrm{CHL} a$ were significantly different among clusters. DO, N$\mathrm{NO}_{3}$ and SRP only showed significant differences in the middle water column and/or at the bottom. Those differences were related to the stratification period. In fact, part of the samples that integrated cluster B and those integrating cluster $\mathrm{C}$ were obtained during summer stratification. As $\mathrm{N}-\mathrm{NH}_{3}$ was not detected in most samples, data concerning this variable are not shown (Table 1). When Daphnia was dominant (Cluster A) mean values of water temperature, conductivity and TP were the lowest. When Dapnhia and Ceriodapnhnia coexisted (Cluster B) mean values of precipitation and CHL $a$ were the highest, and mean values of water transparency were the lowest. When Ceriodapnhnia dominated and coexisted with Diaphanosoma (Cluster C) mean values of water temperature, transparency, conductivity and TP were the highest. Concomitantly, mean values of precipitation were the lowest.

\section{Influence of environmental, biotic factors upon} cladocerans

\section{Availability of edible phytoplankton}

CHL $a$ concentrations were significantly different among clusters. The highest CHL $a$ mean value was recorded in cluster $\mathrm{B}$, whereas the lowest mean value was obtained in cluster C. Samples grouped in cluster A were dominated by Paulschulzia sp. (Chlorophyceae), which represented more than $50 \%$ of all identified taxa. Samples grouped in cluster B were dominated by the centric diatoms. Cyclotella ocellata Pantocksek constituted about $99 \%$ of all centric diatoms identified. Chlamydomonas like cells and Anabaena were also abundant. Samples grouped in cluster $\mathrm{C}$ were dominated by Cyclotella ocellata. In all clusters, small Chlorophyceae such as Scenedesmus spp., Cosmarium spp., Monoraphidium spp., Crucigenia spp., and Oocystis spp. were present in very low densities. Cryptomonas spp. were always present in slightly higher densities than the previously mentioned taxa. The densities of Chlamydomonas like cells, centric diatoms, Paulschulzia sp., Fragilaria spp., Asterionella formosa Hassal and Ceratium hirundinella Schrank significantly differed among clusters (Table 2).

\section{Interactions with a potential competitor}

Since C. numidicus is herbivorous, it was considered to be a potential competitor of cladoceran species. This
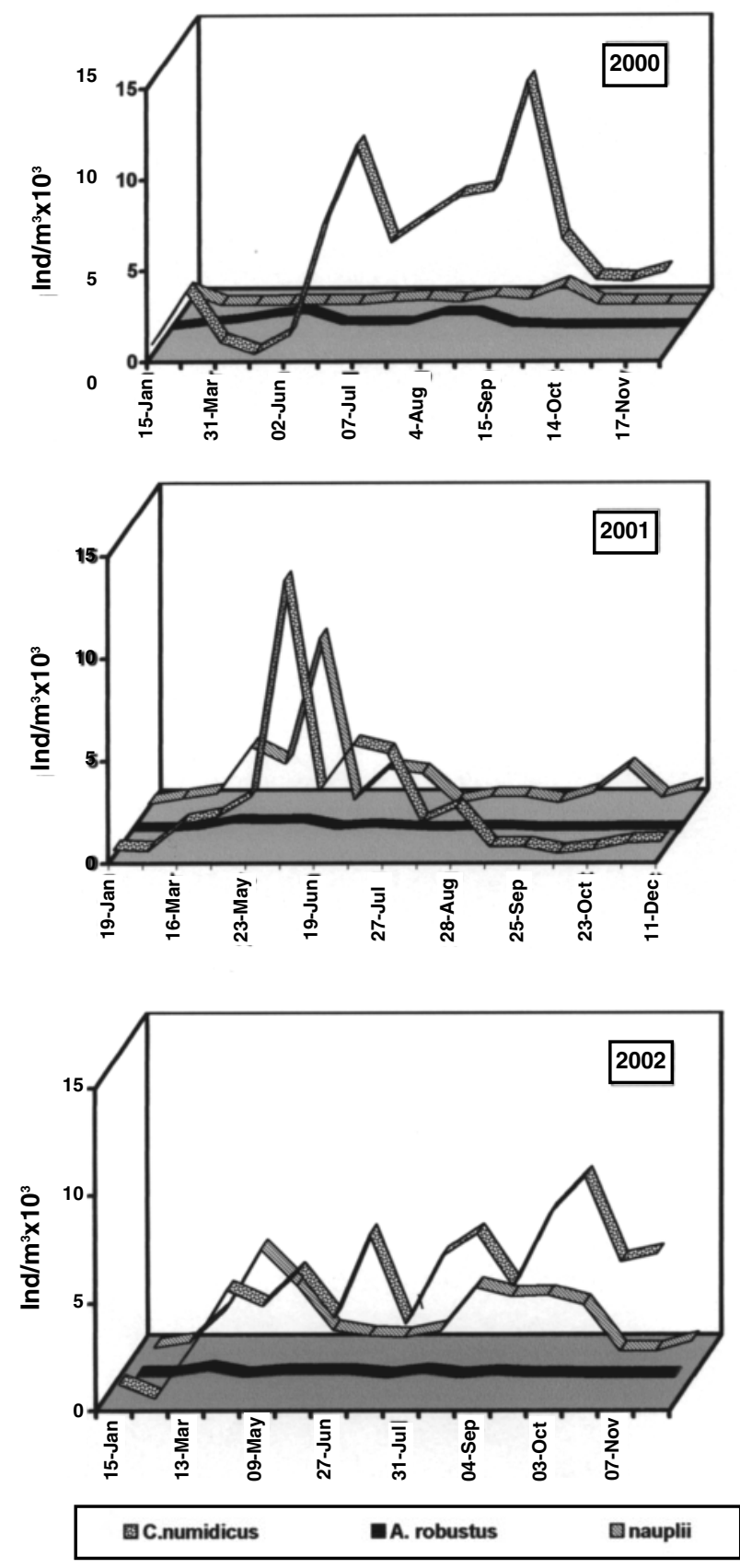

Fig. 5. Seasonal and inter-annual variation of copepod and nauplii densities in Azibo Reservoir.

copepod was always very abundant in Azibo. In addition to the high densities observed all year round, population peaks occurred at the beginning and at the end of summer (Fig.5). Mean densities obtained for each 
Table 2- Mean densities (ind./I X 103), percentage of occurrence (in brackets) of the main phytoplankton taxa in each cluster and results of Kruskal-Wallis test.

\begin{tabular}{|c|c|c|c|c|c|}
\hline \multicolumn{6}{|c|}{ Clusters } \\
\hline Phytoplankton & $\mathbf{A}$ & $\mathbf{B}$ & C & $x^{2}$ & P-values \\
\hline
\end{tabular}

Dimensions: $<\mathbf{5 0} \boldsymbol{\mu m}$
Chlorophyceae

Scenedesmus spp.

Cosmarium spp.

$0.25(0.40) \quad 1.66(0.78) \quad 1.49(0.43)$

2.34

0.273

$0.21(0.34) \quad 0.38(0.18) \quad 3.71(1.07)$

2.03

0.363

Monoraphidium spp.

$0.32(0.50)$

$1.20(0.56)$

$0.11(0.03)$

4.93

0.070

Tetraedron spp.

$0.13(0.20)$

$0.63(0.30)$

$0.46(0.13)$

0.62

0.628

Crucigenia spp.

$0.30(0.48)$

$0.80(0.38)$

$9.38(2.70)$

0.38

0.994

Oocystis spp.

$0.86(1.36)$

$0.28(0.13)$

$0.33(0.09)$

4.56

0.334

Chlamydomonas like

$0.26(0.41) \quad 49.15(23.11) \quad 57.83(16.65)$

7.47

0.031

cells

Bacillariophyceae

Small pennate diatoms

Centric diatoms

$1.11(1.76)$

$0.69(0.33)$

$0.58(0.17)$

1.08

0.350

Cryptophyceae

Cryptomonas spp.

$5.93(9.41)$

$6.11(2.87)$

$8.53(2.46)$

0.15

0.950

Dimensions: $>\mathbf{5 0} \mu \mathrm{m}$

Chlorophyceae

Paulschulzia sp.

Bacillariophyceae

Fragilaria spp.

$$
36.5
$$

Asterionella formosa

Cyanophyceae

Anabaena flos-aquae

Dinophyceae

Ceratium hirundinella

Chrysophyceae

Dinobryon sp.

$36.55(57.96)$

$0.55(0.16)$

7.08

0.031

$1.81(2.87)$

$0.38(0.18)$

$0.12(0.04)$

10.68

0.002

$2.88(4.57)$

$1.77(0.83)$

$0.42(0.12)$

10.84

0.010

$\begin{array}{lllll}5.99(9.51) & 35.25(16.58) & 3.72(1.07) & 0.07 & 0.060\end{array}$

Chlorophyll $a\left(\mu \mathrm{g} \mathrm{I}^{-1}\right)$

Integrated sample

$0.09(0.14) \quad 1.60(0.75) \quad 2.06(0.59)$

12.13

0.005

$0.40(0.63)$

$0.26(0.12)$

$0.12(0.03)$

4.17

0.063

1.4

2.1

0.9

8.28

0.016 
cluster were the following: (A) 2302.3 ind. $/ \mathrm{m}^{3}$; (B) $3868.6 \mathrm{ind} / \mathrm{m}^{3}$ and (C) $6254.5 \mathrm{ind} . / \mathrm{m}^{3}$. Kruskal-Wallis test evidenced significant differences among clusters $\left(\chi^{2}=7.97 ; \mathrm{p}=0.019\right)$. Nauplii were considered together because both $C$. numidicus and $A$. robustus nauplii are herbivorous, therefore functionally alike, and could also act as potential competitors of cladocerans. For cluster A, mean nauplii densities were 916.9 ind.$/ \mathrm{m}^{3}$. For cluster B, mean nauplii densities were 750.5 ind. $/ \mathrm{m}^{3}$. For cluster $\mathrm{C}$ mean nauplii densities were $1542.9 \mathrm{ind} . / \mathrm{m}^{3}$. No significant differences were found among clusters $\left(\chi^{2}=4.99 ; \mathrm{p}=0.083\right)$.

\section{Interactions with potential predators}

Among invertebrate predators, A. robustus, carnivorous in the adult stage, was considered to be a potential predator of the cladocerans. Densities of $A$. robustus were always low, ranging between 0 and 796 ind. $/ \mathrm{m}^{3}$ (Fig. 5). However, this copepod was present in most samples taken during the study period. For cluster A the observed mean density was 229.6 ind. $/ \mathrm{m}^{3}$. For cluster B it was 134.9 ind. $/ \mathrm{m}^{3}$. For cluster $\mathrm{C}$ mean density was $175.1 \mathrm{ind} . / \mathrm{m}^{3}$. No significant differences were found among clusters $\left(\chi^{2}=1.97 ; \mathrm{p}=0.374\right)$. Chaoboridae larvae were not detected in samples during the whole study period.

The potential vertebrate predators present in the reservoir were fish. Only qualitative information provided by anglers was available. Following that information source, fish assemblage was composed of: (1) endemic cyprinid fish : Iberian barbel (Barbus bocagei Steindachner) and Iberian nase (Chondrostoma $d u$ riensis Coelho); (2) carp (Cyprinus carpio Linnaeus); (3) exotic piscivorous : blackbass (Micropterus salmoides Lacepede) and pike (Esox lucius Linnaeus). In addition to the juvenile of all species, only cyprinids would constitute a serious threat as predators. Still according to anglers information it seems that pike became dominant over the other species, presumably as a consequence of the intensity of pike predation over cyprinids. This would diminish predation pressure by cyprinids on cladocerans.

\section{Discussion}

In Azibo, zooplankton community pattern is the reflex of low level disturbance as a consequence of relatively high water residence time and of the small amplitude of water level fluctuations. Several studies undertaken in other regions (e.g. Armengol et al. 1988;
Schmid-Araya \& Zuñiga 1992) corroborate the mentioned pattern. In fact, according to those authors Cladocera and Copepoda were dominant in lake systems where water retention time was large. A seasonal succession was apparent in the cladoceran assemblage, with one or more species dominating in turn as changing conditions and resources became suitable for each. During winter and early spring Daphnia was dominant and Ceriodaphnia was virtually absent. Further on, Daphnia population decreased till undetectable levels. Concomitantly, Ceriodaphnia population increased to its maximum density, becoming dominant from July to September. During this period Daphnia was not detected in samples, meaning that it was present in extremely low densities. Lynch (1978) also observed the replacement of Daphnia by Ceriodaphnia in summer and attributed this phenomenon to the better efficiency of Ceriodaphnia to feed at temperatures above $20^{\circ} \mathrm{C}$. Also susceptible of favouring Ceriodaphnia was the increase in mean TP concentrations during late spring/summer probably caused by particle transportation by wind from reservoir surroundings (e.g. Cole et al. 1990) or senescence of emergent macrophytes that colonise some shallow areas of the reservoir (e.g. James \& Barko 1991). In fact, Tessier et al. (2001) found some evidence that Ceriodaphnia seems to have higher requirements for phosphorus than Daphnia. The depression of Daphnia population could also have been a consequence of the increase in Anabaena mean densities. The negative impacts of this alga on Daphnia ability to feed by reducing filtration rate is well documented (e.g. Lampert \& Sommer 1997). Considering that the highest water temperatures, TP concentrations and Anabaena densities occurred in summer/early autumn in Azibo, it seems possible that in winter and early spring there was an adaptive advantage of Daphnia over Ceriodaphnia and Diaphanosoma, where as in summer/early autumn it was the other way around. The fact that CHL $a$ concentrations were lower than those found in other meso-eutrophic reservoirs of the same region (Geraldes \& Boavida 2003) can be explained by the grazing pressure exerted over edible algae, first by Daphnia and subsequently by Ceriodaphnia and Diaphamosoma. Besides, C. numidicus and nauplii are herbivorous, too. According to Murdoch et al. (1998) herbivorous zooplankton are able to suppress the biomass of edible algae far below the level set by nutrients. In Azibo densities of algae such as Chlamydomonas like cells, Scenedesmus, Crucigenia, Monoraphidium, Cosmarium, Navicula, Nitzschia, Cyclotella and Cryptomonas, which according to Canter-Lund \& Lund (1995), Gonzalez (1998) and Gladyshev et al. (1999) are the main algal groups included in the diet of 
herbivorous zooplankton, were in general very low. Again, this could be a direct consequence of grazing. The significant decrease of CHL $a$ mean concentration during summer months (Cluster $\mathrm{C}$ ) seemed to be related to the reduction in the densities of large algae as well as to the subsequent dominance of small centric diatoms and Chlamydomonas like cells. Concomitantly, water transparency increased. The high mean densities of the latter two algal groups, which are considered edible by herbivorous zooplankton, can be explained by the fact that Cladocera and $C$. numidicus are not strictly herbivorous, but also feed on bacteria, protozoans and detritus (Kerfoot \& Kirk 1991, Gonzalez, 1998 Gladyshev et al. 1999, Schneider-Olt \& Adrian 2001).

The occurrence of several periods of Daphnia and Ceriodaphnia or Diaphanosoma and Ceriodaphnia coexistence, plus the presence of herbivorous copepod $C$. numidicus and of the nauplii of both copepod species in relatively high densities lead to a question: are there any competitive interactions between those species in this reservoir? Data obtained in this study do not provide an objective answer to this question. In fact, several authors reported the existence of competitive interactions in experimental conditions between Daphnia and Ceriodaphnia (Lynch 1978, Smith \& Cooper 1982), between Daphnia and Bosmina (Kurmayer 2001) and between Daphnia and Diaphanosoma (Matveev 1987). However, in Azibo a lack of synchrony was observed in population peaks of Daphnia and $\mathrm{Ce}$ riodaphnia on one hand, and of Daphnia and Diaphanosoma on the other hand. Therefore, one is lead to think that competitive interactions were probably avoided, because species have different ecological optima and consequently utilise resources differently. Consequently, coexistence does not ensure competition because, in general, species explore different ecological niches and resources are not always limiting. In fact, those cladocerans, as well as $C$. numidicus, have different morphological mechanisms for food resource exploitation, which will be reflected on the size of particles each can ingest. According to Lampert \& Sommer (1997), the upper particle size boundary for small cladocerans is about $20 \mu \mathrm{m}$, while for large cladocerans and copepods that limit is about $50 \mu \mathrm{m}$. It can then be concluded that those species might exploit different food resources as a strategy to avoid direct competition. Moreover, as stated above, cladocerans and herbivorous copepods can feed on a broad range of items unselectively: Phytoplankton, protozoans, bacteria and detritus.

Competitive interaction between cladocerans and $C$. numidicus, if actually existed, could have been attenuated by the potential predator prey relationship that might also have existed between $C$. numidicus and $A$. robustus. The evidence that $C$. numidicus was a prey for $A$. robustus was pointed out by Caramujo et al. (1997) in a reservoir located at the Portuguese part of Tejo River watershed where the two species coexisted. However, in Azibo, A. robustus densities were very low and the potential predation pressure over C. numidicus or over some of the cladocerans might have had no significant impact on those populations. According to several authors, in the cladoceran assemblage largebodied cladocerans were especially susceptible to fish predation (Beklioglu \& Moss 1996, Caramujo et al. 1997, Lampert \& Sommer, 1997). Siegfried \& Kopache (1984) observed that the increased predation by $0+$ fish and by planktivorous fish at the beginning of summer lead to a decline in Daphnia population. Up to the nineteen eighties cyprinid fish were dominant in Azibo (Formigo, 1990). Consequently, they could have had some impact on the cladoceran assemblage. According to Vasconcelos (1990) at this time the zooplankton community was dominated by rotifers. This might have been an evidence of the existence of a considerable predation pressure by fish. Cyprinids are not strictly planktivorous, but they can have some impact on Daphnia and on other large-bodied zooplankton in some lakes and reservoirs (Winfield \& Towsend 1992). However, introduction of pike (Esox lucius) in the nineteen nineties lead to an accentuated decrease of the resident cyprinid fish densities. Therefore, the impact of cyprinid predation on cladoceran and copepod assemblages might have been minimised. On the other hand, pike alevins feed on Daphnia and copepods during the first few weeks after absorbing the yolk sac and before they are able to feed on macroinvertebrates (Hunt \& Carbine 1951). In this way, very young pike might have some temporary impact on cladoceran and copepod assemblages as well.

\section{Conclusions}

The present results suggest that complex abiotic/biotic interactions had a direct and strong influence on cladoceran assemblage patterns. However, those interactions and their structural role on the cladoceran assemblage are not fully understood. Thus, further research will be required to clarify points concerning: (1) cladoceran grazing preferences and their impact on phytoplankton community; (2) the existence of competitive relationships among cladocerans and $C$. numi- 
dicus; (3) the predation pressure by A. robustus upon cladocerans and $C$. numidicus (4) the intensity and seasonality of fish predation; (5) the regulation of the above mentioned items by abiotic factors. These topics will be better clarified after complementary experimental field and laboratory work. Although further research is needed, the present study can be regarded as the first evaluation of the ecological role of cladoceran zooplankton in the studied ecosystem. This reservoir is located in a region where an absence of industrial activity, concomitant with low rentability of agriculture, is gradually leading to human desertification. The implementation of new activities such as boating, fishing, pedestrian walks, hunting, bird watching and rural tourism in the reservoir and catchment may constitute economic alternatives to local populations. However, to make those alternatives possible, it is necessary to improve and maintain water quality on a multiple use perspective. In the future, long-term data on the cladoceran assemblage will certainly allow to monitor and predict the effects of human activities on reservoir ecological processes and consequently on water quality. Furthermore, those data will add to the understanding of the limnology of other reservoir ecosystems influenced by Mediterranean climate.

\section{Acknowledgements}

This study was supported by Fundação para a Ciência e a Tecnologia, Portugal (Project Praxis XXI/C/BIA/11012/98) and a doctoral fellowship to AMG (4/5.3/PRODEP/2000). A. Ribeiro, A. Teixeira, N. Marcos and A. Saraiva assisted in field work. M. J. Caramujo kindly identified the copepods. So did S. Almeida and A. J. Calado for diatoms and green algae. J. Sampaio provided local angler information.

\section{References}

APHA 1989. - Standard Methods for the Examination of Water and Wastewater. American Public Health Association, $1587 \mathrm{pp}$.

Armengol J., Sabater F., Riera J.L. \& Puig M.A. 1988. - Longitudinal changes in the zooplankton communities along a series of reservoirs in the Guadiana River (W Spain). Verh. Internat.Verein. Limnol., 23,1006-1010.

Beklioglu M. \& Moss B. 1996. - Mesocosm experiments on the interaction of sediment influence, fish predation and aquatic plants with the structure of phytoplankton and zooplankton communities. Freshwat. Biol., 36, 315-325.

Bossard P. \& Uehlinger U. 1993. - The effect of herbivorous crustacean zooplankton on epilimnetic carbon and phosphorus cycling. Hydrobiologia, 254, 21-34.

Bourrelly P. 1966. - Les Algues d'Eau Douce. I: Les Algues Vertes. Editions N. Boubée, 572 pp.

Bourrelly P. 1968. - Les Algues d'Eau Douce. II: Les Algues Jaunes et Brunes. Editions N. Boubée, 517 pp.

Bourrelly P. 1970. - Les Algues d'Eau Douce. III: Les Algues Bleues et Rouges. Editions N. Boubée, 606 pp.
Canter-Lund H. \&. Lund J.W.G 1995. - Freshwater Algae - their microscopic world explored. Biopress Ltd., 360 pp.

Caramujo M.J., Crispim M.C. \& Boavida M.J. 1997. - Assessment of the importance of fish predation versus copepod predation on life history traits of Daphnia hyalina. Hydrobiologia, 360, 243252.

Cole J. J., Caraco N. F. \& Likens G. E. 1990. - Short-range atmospheric transport: A significant source of phosphorus to an oligotrophic lake. Limnol. Oceanogr., 35, 1230-1237.

Dussart B. 1969. - Les Copepodes des Eaux Continentales d'Europe Occidentale - Tome II : Cyclopoïdes et Biologie. Editions N. Boubée et vie, $500 \mathrm{pp}$.

Formigo N. 1990. - Ictiofauna. Pages 143-169 in: Caracterização ecologica da albufeira do Azibo, com vista à determinação das suas potencialidades no dominio dos recursos vivos. IZAN (eds.) Acções Preparatorias do Programa Integrado de Desenvolvimento Regional de Tras-os-Montes.

Geraldes A.M. \& Boavida M.J. 2003. - Distinct age and landscape influence on two reservoirs under the same climate. Hydrobiologia, 504, 277-288.

Gladyshev M., Temerova T.A., Dubovskaya O.P., Kolmakov V.I. \& Ivanova E.A. - 1999. Selective grazing on Cryptomonas by $\mathrm{Ce}$ riodaphnia quadrangula fed a natural phytoplankton assemblage. Aquat. Ecol., 33, 347-353.

Gonzalez E.J. 1998. - Natural diet of zooplankton in a tropical reservoir (Embalse El Andino, Venezuela). Verh. Internat.Verein. Limnol., 26,1930-1934.

Green R. H. \& Vascotto G. L. 1978. - A method for the analysis of the environmental factors controlling patterns of species composition in aquatic communities. Water Res., 12, 583-590.

Hunt B.P. \& Carbine W.F. 1951. - Food of young pike, Esox lucius L. and associated fishes in Peterson's ditches Houghton Lake Michigan. Trans. Amer. Fish. Soc., 80, 67-83.

James W. F. \& Barko J.W. 1991. - Littoral pelagic phosphorus dynamics during night time convective circulation. Limnol. Oceanogr. 36, 949-960.

Kerfoot W.C. 1978. - Combat between predatory copepods and their prey: Cyclops, Epischura and Bosmina. Limnol. Oceanogr., 23, 1089-1102.

Kerfoot W.C. \& Kirk K.L. 1991. - Degree of taste discrimination among suspension-feeding cladocerans and copepods: Implication for detritivory and herbivory. Limnol. Oceanogr., 36, 11071123 .

Kurmayer R. 2001. - Competitive ability of Daphnia under dominance of non-toxic filamentous cyanobacteria. Hydrobiologia, $442,279-289$.

Lampert W. \& Sommer U. 1997. - Limnoecology - the ecology of lakes and streams. Oxford University Press, $382 \mathrm{pp}$.

Lynch M. 1978. - Complex interactions between natural coexploiters - Daphnia and Ceriodaphnia. Ecology, 59, 552-564.

Margaritora F. 1983. - Guide per il Riconoscimento delle Specie Animali delle Acque Interne Italiane. 22 Cladoceri (Crustacea: Cladocera). Consiglio Nazionale delle Ricerche, 169 pp.

Matveev V.F. 1987. - Effect of competition on the demography of planktonic cladocerans - Daphnia and Diaphanosoma. Oecologia, 74, 468-477.

Murdoch W.W., Nisbet R.M, McCauley E., DeRoos A.M. \& Gurney W.S.C. 1998. - Plankton abundance and dynamics across nutrient levels: Tests of hypotheses. Ecology, 79, 1339-1356.

Murphy J. \& Riley J.P. 1962. - A modified single solution method for the determination of phosphate in natural waters. Anal. Chim. Acta, 27, 31-36.

Schneider-Olt B. \& Adrian R. 2001. - Trophic interactions between crustacean and protozoan plankton. Verh. Internat.Verein. Limnol., 27, 3705-3707. 
Schum J.E. \& Maly E.J. 2000. - Complex interactions among aquatic insect larvae and Daphnia in a small pond ecosystem. Verh. Internat.Verein. Limnol., 27, 1784-1787.

Scourfield I.S.O. \& Harding J.P. 1966. - A key to British freshwater Cladocera. Freshwater Biological Association, 55 pp.

Siegfried C.A. \& Kopache M.E. 1984. - Zooplankton dynamics in a high mountain reservoir of southern California. Calif. Fish and Game, 70, 18-38.

Schmid-Araya J.M. \& Zuñiga L.R. 1992. - Zooplankton community structure in two Chilean reservoirs. Arch. Hydrobiol., 123, 305335.

Smith D.W. \& Cooper S.D. 1982. - Competition among Cladocera. Ecology, 63, 1004-1015.

Sommer F., Santer B., Jamieson C., Hansen T. \& Sommer U. 2003. - Daphnia population growth but not moulting is a substancial phosphorus drain for phytoplankton. Freshwat. Biol., 48, 67-74.
SPSS 1998. - SYSTAT 8.0 Language Reference. SPSS Inc., 276 pp. Tessier, A.J., Bizina E.V. \& Geedey C.K. 2001. - Grazer-resource interactions in plankton : Are all daphniids alike? Limnol. Oceanogr. 46, 1585-1595.

Utermöhl H. 1958. - Zur Vervolkommnung der Quantitativen Phytoplankton -Methodik. Mitt. Int. Verein. Limnol., 9, 1-38.

Vasconcelos V.M. 1990. - Seasonal fluctuation in the zooplankton community of Azibo Reservoir (Portugal). Hydrobiologia, 196, 183-191.

Wetzel, R. G., 2001. - Limnology - Lake and River Ecosystems. 3rd Edition. Academic Press, 1006 pp.

Winfield I.J. \& Townsend C.R., 1992. - The role of cyprinids in ecosystems. Pages 552-567 in Cyprinid Fishes, Systematics, Biology and Exploitation. I.J.Winfield \& J.S. Nelson (eds.). Chapman \& Hall. 